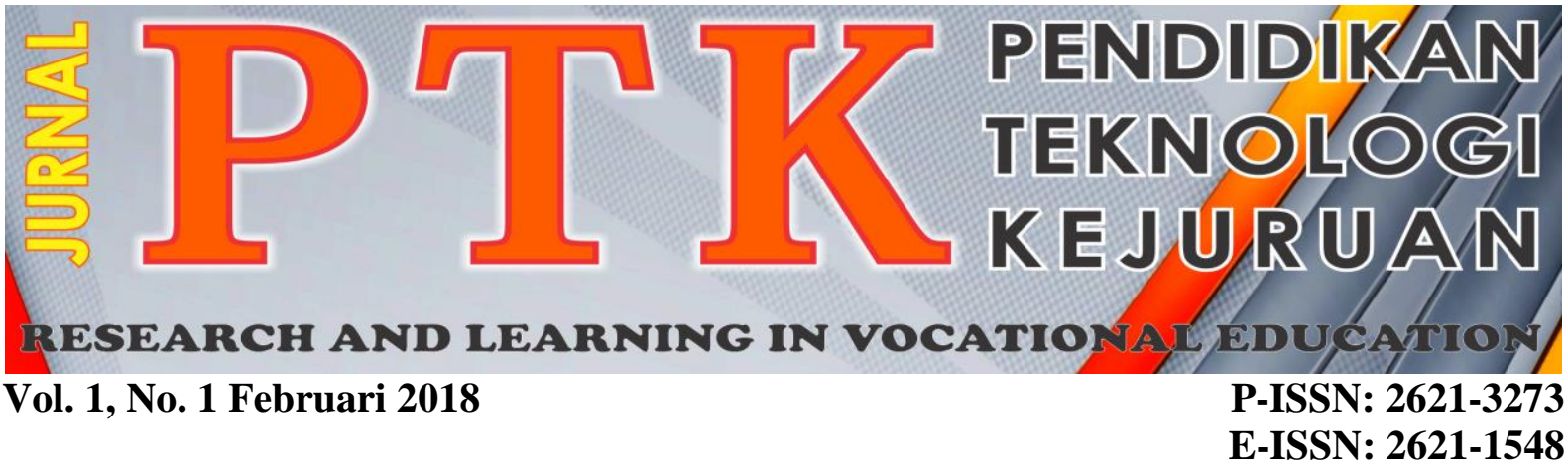

\title{
PENGEMBANGAN KOMPETENSI PRODUKTIF KEAHLIAN TEKNIK KENDARAAN RINGAN SMK N I GUGUAK KABUPATEN 50 KOTA
}

\author{
M Giatman ${ }^{1}$, Antoni ${ }^{2}$, Syahril ${ }^{3}$ dan Hasan Maksum ${ }^{4}$ \\ ${ }^{1234}$ Program Studi Pendidikan Teknologi dan Kejuruan, Fakultas Teknik, Universitas Negeri Padang \\ ${ }^{*}$ Corresponding author, e-mail: antoni_payakumbuh@yahoo.com
}

\begin{abstract}
Abstrak-Penelitian ini bertujuan untuk mengembangkan kompetensi produktif sesuai dengan perkembangan ilmu pengetahuan dan teknologi. Jenis penelitian ini Research and Development, pengumpulan data menggunakan metode Delphi. Jumlah responden Responden 45 orang yang terdiri dari: 24 teknisi bengkel otomotif 11 guru SMK dan yang rekayasa kendaraan ringan, dan 10 orang dosen. Berdasarkan hasil pengolahan data ditemukan 58,8\% kompetensi sangat penting dipelajari oleh siswa karena relevan dengan kebutuhan bisnis atau industri, 38,2\% kompetensi penting dan relevan dengan kebutuhan bisnis atau industri, dan hanya $2,94 \%$ kompetensi kurang relevan dengan kebutuhan tempat kerja. Meskipun kompetensi nya sudah banyak yang relevan, masih perlu disesuaikan dengan perkembangan teknologi terbaru di bidang otomotif seperti: elektronik otomotif dan sistem manajemen
\end{abstract}

Kata kunci : kompetensi produktif, metode delphi

\begin{abstract}
This study aims to develop a productive competence in accordance with the development of science and technology. This type of research is research and development, data collection using the Delphi method. The number of respondents 45 people consisting of: 24 automotive repair technicians, 11 light vehicle engineering vocational school teachers, and 10 lecturers. Based on the results found $58.8 \%$ of data processing is critical competencies learned by the students because it is relevant to the needs of the business or industry, $38.2 \%$ essential competencies and relevant to the needs of the business or industry, and only $2.94 \%$ less competence relevant to the needs of the workplace. Despite his competence has much of relevant, need to be adjusted to the latest technological developments in the automotive field such as automotive electronics and engine management systems
\end{abstract}

Keywords: productive competency, delphi method

Copyright $\odot 2018$ JPTK. All rights reserved

\section{Pendahuluan}

Pendidikan Teknologi dan Kejuruan salah satu lembaga yang mempersiapkan tenaga kerja terdidik di bidang kejuruan untuk menciptakan tenaga yang mampu membangun usaha mandiri produktif dengan modal kecil namun mampu menyerap tenaga kerja yang lebih banyak. Oleh sebab itu kurikulum Pendidikan Teknologi dan Kejuruan harus mengarah dan mendukung terciptanya tenaga kerja terdidik, disamping mampu menciptakan lapangan kerja.
Ada beberapa bidang usaha/ pekerjaan yang dapat ditekuni oleh lulusan Program keahlian Otomotif kompetensi keahlian Teknik Kendaraan Ringan SMK yaitu, membuat bengkel sendiri, bekerja di bengkel / dunia industri, atau melanjutkan ke perguruan tinggi. Namun kenyataannya tamatan SMK telah menjadi penyumbang pengangguran terbanyak. Data BPS 2010 13,81\% dari penganguran terbuka berasal dari tamatan SMK, persentase tersebut dari tahun ke tahun menurun, tetapi jumlahnya masih tetap yang tertinggi. 
Keterserapan tamatan SMK di dunia kerja, Samsudi (2008:1) menjelaskan idealnya lulusan SMK yang bisa langsung memasuki dunia kerja sekitar $80-85 \%$, sedang selama ini yang terserap baru 61\%. Pada tahun 2006 lulusan SMK di Indonesia mencapai 628.285 orang, sedangkan proyeksi penyerapan atau kebutuhan tenaga kerja lulusan SMK tahun 2007 hanya 61,43\%. Sedangkan pada data Dinas Sosial Tenaga Kerja Kota Payakumbuh tercatat pencari kerja yang berlatar belakang pendidikan SMK Program keahlian Mesin dan Otomotif sebanyak 290 orang. Begitu juga data Alumni SMK N I kec. Guguak Kab Lima Puluh Kota, diketahui hanya sedikit sekali tamatan yang bekerja di perbengkelan dan di dunia industri apalagi membuka perbengkelan sendiri.

Berdasarkan wawancara dengan beberapa teknisi bengkel otomotif di kabupaten Lima Puluh Kota dan Kota Payakumbuh, bengkel lebih banyak membutuhkan kompetensi/keahlian baru seperti Elektronik Fuel Injection (EFI), Variable Valve Timing Intelegence (VVTi), Diagnosis Throuble Code (DTC), EMS (Electronic Management System), EGI (Electronic Gasoline Injection), EPI (Electronic Petrol Injection), PGM-FI (Programmed Fuel Injenction) VITEC, ESA, IAA, Dli, ABS, dan Power stearing. Kompetensi-kompetensi tersebut belum menjadi kompetensi produktif pada kurikulum keahlian Teknik Kendaraan Ringan. Oleh karena itu sekolah perlu mengembangkan kurikulum dengan kompetensi yang sesuai dengan kebutuhan Dudi, sehingga memungkinkan untuk dipergunakan oleh lulusan untuk masuk dunia kerja.

Sesuai dengan permasalahan, maka tujuan penelitian ini adalah untuk mengetahui relevansi kompetensi produktif Kurikulum keahlian Teknik Kendaraan Ringan pada SMK N 1 Kec. Guguak dengan kebutuhan Dudi.

Karakteristik pendidikan kejuruan menurut Finch dan Crunkilton semestinya: 1) Diarahkan untuk memper-siapkan peserta didik memasuki lapangan kerja, 2) didasarkan atas kebutuhan dunia kerja, 3) fokus pada penguasaan pengetahuan, keterampilan, sikap dan nilainilai yang dibutuhkan oleh dunia kerja, 4) penilaian yang sesungguhnya terhadap kesuksesan peserta didik harus pada "handson" atau performance dalam dunia kerja, 5) hubungan yang erat dengan dunia kerja merupakan kunci keberhasilan, 6) responsif dan antisipatif terhadap kemajuan teknologi, 7) lebih ditekankan pada "learning by doing", 8), memerlukan fasilitas yang mutakhir untuk praktek sesuai dengan tuntutan dunia usaha dan industry [1].

Badan Kepegawaian Negara dalam peraturan Nomor: 46A Tahun 2003 Tanggal 21 November 2003 mengatakan bahwa kompetensi adalah kemampuan dan karakteristik yang dimiliki seorang berupa pengetahuan, keterampilan, dan sikap perilaku yang diperlukan dalam pelaksanaan tugas jabatannya, sehingga orang tersebut dapat melaksanakan tugasnya secara profesional, efektif, dan efisien. Dengan dikuasainya kompetensi tersebut oleh seseorang, maka yang bersangkutan akan mampu: a) Bagaimana mengerjakan suatu tugas atau pekerjaan, b) bagaimana mengorganisasikannya agar pekerjaan tersebut dapat dilaksanakan, c) apa yang harus dilakukan bilamana terjadi sesuatu yang berbeda dengan rencana semula, d) bagaimana menggunakan kemampuan yang dimilikinya untuk memecahkan masalah atau melaksanakan tugas dengan kondisi yang berbeda.

Mata Pelajaran yang yang harus dipelajari oleh siswa SMK ada tiga, yaitunya pelajaran adaptif, normatif dan produktif. Mata pelajaran Produktif atau lebih lazim disebut kompetensi produktif dikelompokkan atas Dasar Kompetensi Kejuruan dan Kompetensi Kejuruan. Djohar Asari mengatakan Kompetensi Produktif pada SMK secara substansif adalah program produktif yang memberikan bimbingan pembelajaran berbasis kompetensi dan kerja proyek di dalam bidang teknologi [2]. Kompetensi keahlian atau kompentesi produktif adalah kemampuan seseorang yang terobservasi mencakup atas pengetahuan, keterampilan, sikap kerja dan hasil kerja (produk) yang sesuai dengan standar kerja bidang keahlian tersebut [3]. Tujuannya membentuk kompetensi dan kemampuan berpikir peserta didik secara sistematis, kritis dan kreatif dalam bidang teknologi yang berguna untuk memecahkan permasalahan dalam kehidupannya sehari-hari, baik di tempat kerja maunpun masyarakat serta membentuk pengetahuan yang menjadi dasar bagi pendidikan selanjutnya.

Oleh karena itu pengembangan kurikulum SMK harus diarahkan untuk mempersiapkan siswa memasuki lapangan kerja sebagai SDM yang siap pakai, baik untuk bekerja atau menciptakan lapangan pekerjaan sendiri [1]. Sementara itu pengembangan standar kompetensi pada kurikulum perlu dilakukan secara berkala sesuai perkembangan teknologi dan ilmu pengetahuan. Steven R. Aragon, cs mengatakan 
Standar kompetensi atau keahlian mempunyai dua muatan, yaitunya a) Deskripsi tanggung jawab untuk suatu pekerjaan dan b) deskripsi Pengetahuan dan keterampilan yang diperlukan untuk melakukan suatu tangguang jawab [4].

Judisseno berpendapat, lembaga pendidikan merupakan pihak yang bertanggungjawab menciptakan dan menyuplai tenaga kerja bagi industry [5]. Oleh karena itu, lembaga pendidikan dituntut untuk memberikan SDM yang sesuai dengan permintaan dan kebutuhan industri. Dalam kaitan ini, lembaga pendidikan harus menciptakan SDM yang kompeten dan organisasi bisnis harus mampu mendefinisikan kompetensi apa yang dibutuhkan. Keduanya harus saling bersinergi dalam suatu kemitraan, dan secara konsisten dapat mendefinisikan dan menciptakan pola tenaga kerja yang kompeten pada bidang masing-masing.

Carrie DuPre dan Kate Williams, cara yang paling efektif bagi lulusan untuk memenangi persaingan pasar kerja adalah membuktikan bahwa mereka memiliki kemampuan yang tidak saja dibidang teknologi industry atau keterampilan/ skill, tetapi kemampuan lain yang juga dibutuhkan adalah keterampilan komunikasi, analitis, kerja sama dalam tim, dan etika kerja yang kuat [6].

Kerangka konseptual penelitian ini dapat dilihat pada gambar 1 berikut.
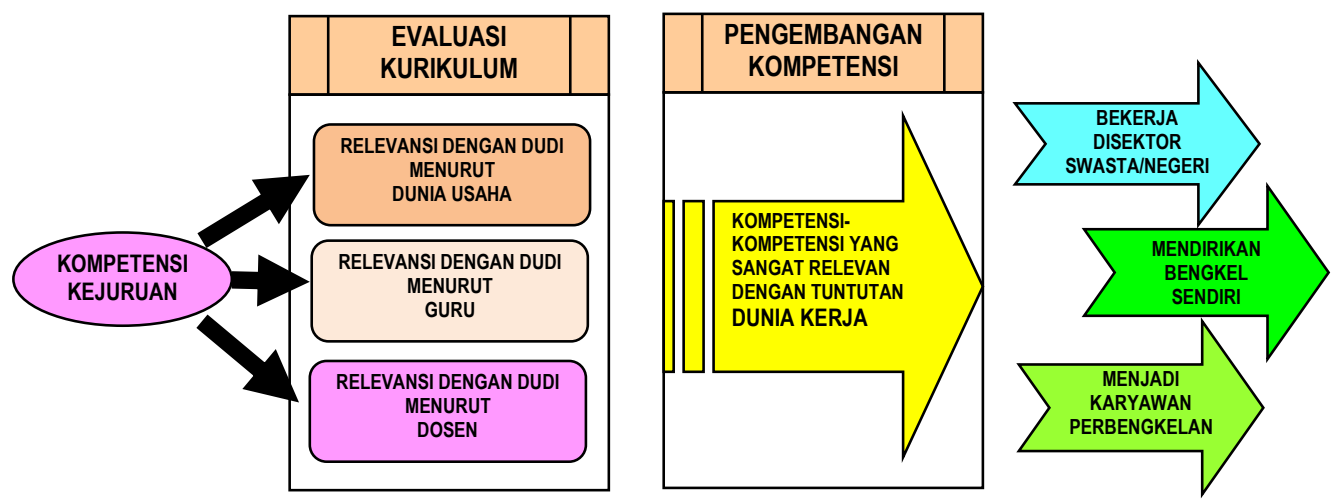

Gambar 1. Kerangka Konseptual

\section{METODE PENELITIAN}

Objek penelitian ini adalah kompetensi produktif kurikulum program keahlian Teknik Otomotif keahlian Teknik Kendaraan Ringan SMK N 1 Kec. Guguak Kabupaten Lima Puluh Kota. Penelitian ini berbentuk Research and Development atau penelitian pengembangan. Menurut Sugiyono penelitian pengem bangan adalah metode penelitian yang digunakan untuk menghasilkan produk tertentu [7]. Karena yang kita lakukan adalah pengembangan kurikulum yang sudah ada maka penelitian ini kita lakukan dengan teknik penelitian metode Delphi.

Teknik Delphi, adalah suatu cara untuk mendapatkan konsensus diantara para pakar melalui pendekatan intuitif. Dipilihnya metode Delphi karena metode inilah yang paling cocok untuk mengatasi masalah penelitian ini karena melibatkan berbagai unsur, dan dilakukan kros cek (peninjauan) terhadap permasalahan pada saat pembahasan dengan nara sumber [8]. LangkahLangkah penerapan Teknik Delphi dalam penelitian pengembangan adalah sebagai berikut (gambar2).

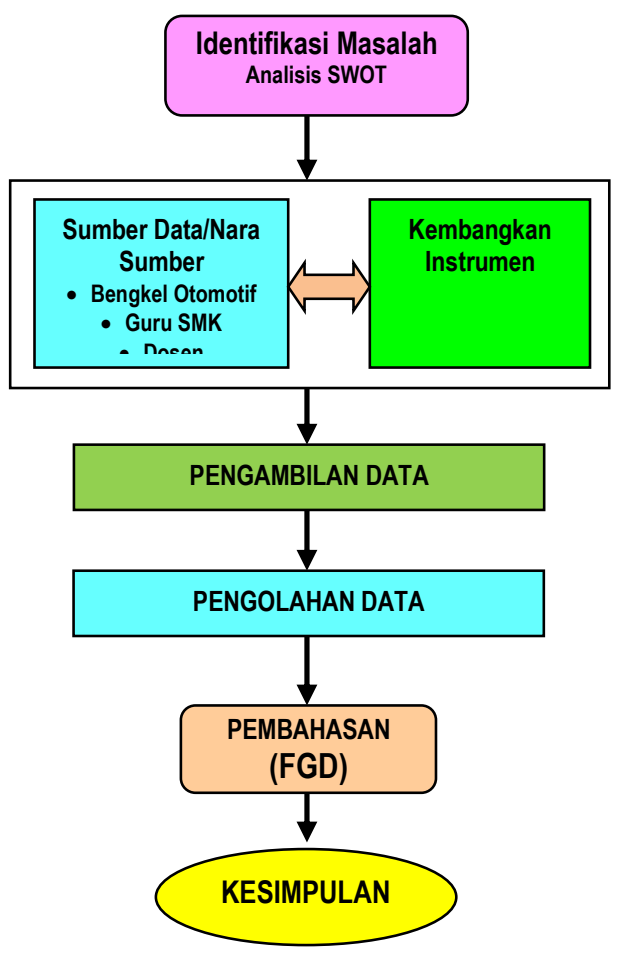

Gambar 2. Prosedur Penelitian 
Peneliti melakukan analisis SWOT terhadap permasalahan yang ada dengan mengidentifikasi isu dan masalah yang berkembang di sekolah, permasalahan yang melatar belakangi, atau permasalahan yang dihadapi yang harus segera perlu penyelesaian.

Berdasarkan bidang permasalahan dan isu yang telah teridentifikasi, bahwa dalam pengembangan kurikulum Teknik Kendaraan Ringan ini perlu melibatkan berbagai pihak yaitu Perusahaan jasa perbengkelan otomotif di Kabupaten Lima Puluh Kota dan Kota Payakumbuh, Guru keahlian Teknik Kendaraan Ringan pada SMK Negeri 1 Kecamatan Guguak Kabupaten Limapuluh Kota, dan Dosen Teknik Otomotif pada Fakultas Teknik Universitas Negeri Padang.

Instrumen yang digunakan untuk pengumpulan data penelitian ini adalah kuesioner/ angket. Kuesioner yang digunakan adalah kuesioner model Rating Scale [9], yaitunya skala 4; 3; 2; dan 1 .

Data yang sudah dikumpulkan melalui instrumen penelitian berupa kuesioner. Untuk mengetahui tingkat relevansi masing-masing kompetensi dengan dunia kerja diolah dengan program microsoft excel dengan rumus sebagai berikut :

Tkt Pencapaian $=\frac{\text { JumlahSkor }}{\text { SkorIdealMak }} \times 100 \%$

Rentang kategori ketercapaian rele vansi menurut responden ditetapkan seba gai berikut (Tabel 1).

Tabel 1. Rentang Ketercapaian Relevansi

\begin{tabular}{cl}
\hline $\begin{array}{c}\text { Rentang } \\
\text { Persentase }\end{array}$ & \multicolumn{1}{c}{ Kategori } \\
\hline $81-100 \%$ & $\begin{array}{l}\text { Sangat Relevan dan sangat } \\
\text { penting diajarkan kepada siswa. }\end{array}$ \\
\hline $66-80 \%$ & $\begin{array}{l}\text { Relevan dan penting diajarkan } \\
\text { kepada siswa. }\end{array}$ \\
\hline $56-65 \%$ & $\begin{array}{l}\text { Kurang Relevan dan kurang } \\
\text { penting diajarkan kepada siswa. }\end{array}$ \\
\hline $0-55 \%$ & $\begin{array}{l}\text { Tidak Relevan dan tidak perlu } \\
\text { diajarkan pepada siswa. }\end{array}$ \\
\hline
\end{tabular}

Untuk membahas hasil temuan diundang responden yang terdiri dari dunia usaha/dunia industri, guru-guru program keahlian otomotif dan staf pengajar Program Studi Otomotif Fakultas Teknik UNP dalam bentuk Focus Group Discussion (FGD) untuk menyampaikan relevansi kurikulum dengan kebutuhan dunia kerja, kompetensi lain yang dibutuhkan Du/Di serta rekomendari muatan kurikulum. Pada kesempatan tsb peneliti juga mengundang Kepala Dinas Pendidikan, pengawas dan kasi kurikulum pada Dinas Pendidikan, Kepala Sekolah dan wakil kepala sekolah.

\section{HASIL DAN PEMBAHASAN}

Berdasarkan pengolahan data hasil penelitian, dapat dijelaskan sebagai berikut:

\section{Relevansi Kompetensi Produktif dengan Du/Di Menurut Teknisi bengkel}

Dari 102 item pertanyaan tentang kom petensi dasar muatan kurikulum keahlian teknik otomotif, 59\% dari kompetensi ter sebut sangat reevan dengan kebutuhan Dudi, 38\% menyatakan relevan, dan $3 \%$ kurang relevan, dan tidak ada $(0 \%)$ yang menyatakan tidak relevan Tabel 2).

Jadi menurut praktisi dunia kerja, kompetensi muatan kurikulum pada teknik kendaraan ringan masih relevan dengan dunia kerja, Cuma substansi kualitas dari isi kurikulum harus selalu ditingkatkan sesuai dengan perkembangan zaman

Tabel 2. Relevansi Kompetensi Produktif dengan Du/Di Menurut Teknisi bengkel

\begin{tabular}{lcc}
\hline \multicolumn{1}{c}{ Rentang Persentase } & Frek & $\begin{array}{c}\text { Persentase } \\
\text { Frek (\%) }\end{array}$ \\
\hline $\begin{array}{l}\text { Tidak Relevan rentang }(0- \\
55 \%)\end{array}$ & 0 & 0.00 \\
\hline $\begin{array}{l}\text { Kurang Relevan rentang } \\
(56 \%-5 \%)\end{array}$ & 3 & 3 \\
\hline $\begin{array}{l}\text { Relevan rentang (66\%- } \\
80 \%)\end{array}$ & 39 & 38 \\
\hline $\begin{array}{l}\text { Sangat Relevan rentang } \\
(81 \%-100 \%)\end{array}$ & 60 & 59 \\
\hline \multicolumn{1}{c}{ Total } & $\mathbf{1 0 2}$ & $\mathbf{1 0 0}$ \\
\hline
\end{tabular}

\section{Relevansi Kompetensi Produktif dengan Du/Di Menurut Guru}

Tidak jauh berbeda dengan pandangan teknisi bengkel, dari pandangan guru diperoleh, 59\% dari kompetensi tersebut sangat reevan dengan kebutuhan Dudi, 38\% menyatakan relevan, dan 3 $\%$ kurang relevan, dan tidak ada (0\%) yang menyatakan tidak relevan Tabel 3). 
Tabel 3: Relevansi Kompetensi Produktif dengan Du/Di Menurut Guru

\begin{tabular}{lcc}
\hline \multicolumn{1}{c}{ Rentang Persentase } & $\begin{array}{c}\text { Frek } \\
(\mathbf{f})\end{array}$ & $\begin{array}{c}\text { Persentase } \\
\text { Frek (\%) }\end{array}$ \\
\hline $\begin{array}{l}\text { Tidak Relevan rentang }(0 \\
-55 \%)\end{array}$ & 0 & 0.00 \\
\hline $\begin{array}{l}\text { Kurang Relevan rentang } \\
(56 \%-5 \%)\end{array}$ & 9 & 9 \\
\hline $\begin{array}{l}\text { Relevan rentang (66\%- } \\
80 \%)\end{array}$ & 23 & 22 \\
\hline $\begin{array}{l}\text { Sangat Relevan rentang } \\
(81 \%-00 \%)\end{array}$ & 70 & 69 \\
\hline Total & $\mathbf{1 0 2}$ & $\mathbf{1 0 0}$ \\
\hline
\end{tabular}

Dari tebel 3, diketahui 69\% kompe tensi sangat relevan dengan kebutuhan $\mathrm{Du} / \mathrm{Di}, 22 \%$ kompetensi relevan dan 9\% kompetensi kurang relevan, tidak ada kom petensi dasar yang tidak relevan dengan kebutuhan Du/Di.

Berarti menurut Guru kompetensi muatan kurikulum keahlian teknik kendaraan ringan masih relevan dengan dunia kerja dan "sangat penting" diajarkan kepada siswa, cuma subtansi atau kualitas dari isi kurikulum tersebut harus selalu ditingkatkan sesuai dengan perkembangan zaman, serta harus diikuti dengan mening katkan kompetensi guru, sarana prasarana sesuai dengan peningkatan teknologi.

\section{Relevansi Kompetensi Produktif dengan Du/Di Menurut Menurut Dosen}

Dari 102 item pertanyaan tentang kompetensi dasar muatan kurikulum keahlian teknik otomotif, 63\% dari kompetensi tersebut sangat reevan dengan kebutuhan Dudi, 33\% menyatakan relevan, dan $4 \%$ kurang relevan, dan tidak ada (0\%) yang menyatakan tidak relevan Tabel 4).

Tabel 4: Relevansi Kompetensi Produktif Menurut Dosen

\begin{tabular}{|l|c|c|}
\hline \multicolumn{1}{|c|}{ Rentang Persentase } & $\begin{array}{c}\text { Frek } \\
(\mathbf{f})\end{array}$ & $\begin{array}{c}\text { Persentase } \\
\text { Frek (\%) }\end{array}$ \\
\hline $\begin{array}{l}\text { Tidak Relevan rentang }(0 \\
-55 \%)\end{array}$ & 0 & 0.00 \\
\hline $\begin{array}{l}\text { Kurang Relevan rentang } \\
(56 \%-65 \%)\end{array}$ & 4 & 4 \\
\hline $\begin{array}{l}\text { Relevan rentang (66\% - } \\
80 \%)\end{array}$ & 34 & 33 \\
\hline $\begin{array}{l}\text { Sangat Relevan rentang } \\
(81 \%-00 \%)\end{array}$ & 64 & 63 \\
\hline Total & $\mathbf{1 0 2}$ & $\mathbf{1 0 0}$ \\
\hline
\end{tabular}

Jadi menurut Dosen kompetensi muatan kurikulum kelompok keahlian teknik kendaraan ringan masih relevan dengan dunia kerja dan "sangat penting" diajarkan kepada siswa, cuma subtansi atau kualitas dari isi kurikulum tersebut harus selalu ditingkatkan sesuai dengan perkembangan zaman.

Meski berdasarkan data diatas kompetensi muatan kurikulum keahlian teknik kendaraan ringan banyak yang relevan, perlu juga ditambahkan beberapa kompetensi atau teknologi terbaru dibidang otomotif, yaitu Elektronika Otomotif dan Engine Manajemen Sistem. Dengan demikian "Pengembangan kurikulum bukanlah pada perubahan materi melainkan pengembangan pada subtansi atau materi yang diajarkan, sesuai dengan perkembangan ilmu pengetahuan dan teknologi". Hal ini dapat juga dilakukan melalui kegiatan seminar.

Disamping kompetensi yang sudah ada dikembangkan, juga disarankan oleh responden responden beberapa kompetensi baru, yaitu: Dasar-dasar sistem elektronik otomotif, Perawatan sistem elektronik atau ototronik, Sistem bahan bakar elektronik, Sistem rem ABS, Perbaikan sistem bahan bakar diesel, Sistem elektronik, Sistem Control, Mickro Prosessor, Sensor, Tranduser, dan Etika kerja di dunia usaha dan dunia industri.

\section{KESIMPULAN DAN SARAN}

Kesimpulan Penelitian ini adalah perlu pengembangan kompetensi produktif muatan kurikulum secara berkala sesuai dengan perkembangan teknologi dan ilmu pengetahuan dengan melibatkan berbagai pihak terkait, sehingga dapat menghasilkan lulusan atau tamatan yang benar-benar dibutuhkan oleh dunia kerja.

Pengembangan kurikulum bukanlah pada perubahan mata ajar, melainkan pengembangan pada subtansi atau materi yang diajarkan, sesuai dengan perkem bangan ilmu pengetahuan dan teknologi. Materi yang perlu ditambahkan berupa teknologi terbaru dibidang otomotif, yaitu Elektronika Otomotif dan Engine Manajemen Sistem seperti yang disarankan pada kegiatan seminar

\section{DAFTAR PUSTAKA}

[1] Finch Curtis R and C. J. R, Chapter 7 Curriculum Development In Vocational and Technical Education. Virginia Polytechnic Institute and State University: Allyn and Bacon, Inc., 1984.

[2] D. Asari and P. Imam, Mode-model Pembelajaran pada Kelompok Mata Diklat Produktif DI SMK. Universitas Pendidikan Indonesia dan Pusat Pengembangan Penataran Guru Teknologi Bandung, 2006. 
[3] N. Jalinus and R. A. Nabawi, "Implementation of the PjBL Model to Enhance Problem Solving Skill and Skill Competency of Community College Student," J. Pendidik. Vokasi, vol. 7, no. 3, pp. 304-311, 2017.

[4] Steven R. Aragon, Hui-Jeong Woo, Matthew R. Marvel, -Journal of Career and Technical Education, 21(2), Spring, 2005 - Page 35. 2005

[5] Judisseno, Rimsky.K, Jadilah Pribadi yang Kompeten di Tempat Kerja, Jakarta: PT. Gramedia Pustaka Utama. 2008.

[6] Carrie DuPre, Kate Williams. Undergraduates' Perceptions of Employer Expectations, Journal of Career and
Technical Education, Vol. 26, No. 1, Clemson UniversitySpring, 2011.

[7] Sugiyono. Metode Penelitian Kuantitatif, Kualitatif dan $R \& D$, Penerbit Alfabeta, Bandung, 2010.

[8] Tim Puslitjaknov. Metode Penelitian Pengembangan, Pusat Penelitian Kebijakan dan inovasi Pendidikan, Badan Penelitian dan Pengembangan Departemen Pendidikan Nasional, 2008.

[9] Ary Donald, Jacobs Lucy Cheser, dan Razavieh Asghar. Introduction to Reseach in Education, Third Edition, Holt, Rinehart and Winston, Nothern Illionois University, 1982. 